\title{
Inheritance of Seed Protein Subunits of Common Buckwheat (Fagopyrum esculentum Moench) Cultivar Sobano and Its Homostylous Wild Type
}

\author{
Jian-Hui $\mathrm{Li}^{1}$ \& Qing-Fu Chen ${ }^{1}$ \\ ${ }^{1}$ Research Center of Buckwheat Industry Technology, Institute of Plant Genetics and Breeding, Guizhou \\ Normal University, Guiyang, P.R. China \\ Correspondence: Qing-Fu Chen, Research Center of Buckwheat Industry Technology, Institute of Plant \\ Genetics and Breeding, Guizhou Normal University, Baoshan Beilu 116, Guiyang 550001, P.R. China. \\ E-mail: cqf1966@163.com
}

Received: February 21, 2014 Accepted: March 18, 2014 Online Published: May 15, 2014

doi:10.5539/jas.v6n6p1

URL: http://dx.doi.org/10.5539/jas.v6n6p1

\begin{abstract}
The seed protein subunits of common buckwheat Sobano (Fagopyrum esculentum) and its homostylous wild type "HOMO" (F.esculentum var. homotropicum) were studied by means of SDS-PAGE analysis. The results showed that there are 33 bands of seed protein subunits in Sobano and 31 bands in HOMO. Most of them were found in the cotyledon and a few in the endosperm. There are nine subunits in Sobano seeds and ten subunits in HOMO. The inheritance analysis of the seed protein subunits in progenies of hybrids between Sobano and HOMO showed that there are four pairs of protein subunits controlled by a single co-dominant allele. The genetic analysis of morphological characters indicated that homostyly, shattering and acute achenes are controlled by different dominant single genes. The shattering gene has a linkage to the homostyly locus in a rate of $7.81 \%$ and to the allele PS44/PS42.9 in a rate of $22.54 \%$.
\end{abstract}

Keywords: buckwheat, SDS-PAGE, seed protein subunits, homostyly, shattering, acute achene, gene linkage

\section{Introduction}

Common buckwheat (Fagopyrum esculentum) is the key domesticated species mainly grown in the temperate zones of the northern hemisphere: Europe, China, North America, Korea and Japan (Campbell, 1997). The homostylous wild type is close relative to common buckwheat distributed in the Yunnan and Sichuan provinces of China (Chen, 2012). The buckwheat fruit is an achene consisting of an endosperm and an embryo being covered by a testa and a pericarp. The protein content ranges from 8.51 to $18.87 \%$ depending on the cultivar (Krkoskova \& Mrazova, 2005). The storage protein prolamin and glutelin contents of buckwheat, however, are very low. Albumin and globulin are the major storage proteins in buckwheat seeds (Guo \& Yao, 2006; Tang \& Wang, 2010). The 13S salt soluble globulin is the most important one (Radovic et al., 1996; Khan et al., 2012). One of the 13S globulin fractions is expressed within the range of 32-43 kDa, the other between 23-25 kDa (Maksimovic et al. 1996). Buckwheat proteins are characterized by their high nutritional and biological values (Bonafaccia et al., 2003).

Buckwheat seed protein subunits have been revealed useful as genetic markers for cultivar identification (Rogl \& Javornik, 1996; Dvoracek et al., 2004; Nalecz et al., 2009) and for species identification (Lazareva \& Fesenko, 2004; Rout \& Chrungoo, 2007; Li et al., 2008). Zeller et al. (2004) used the electropherograms of the 13S globulin fractions for genetic studies.

The aim of the present study is the identification and characterization of the seed protein subunits of the common buckwheat cultivar Sobano, its wild type and the inheritance of several genes in the progenies of hybrids between them. A further objective is the inheritance of the morphological traits homostyly, shattering, and acute achene.

\section{Material and Methods}

\subsection{Plant Material and Crossing Plan}

Seeds of the common buckwheat cultivar Sobano possessing dimorphic flowers (heterostyle) and the wild type HOMO with homomorphic flowers (homostyle) were kindly provided by South-West Seed Company (SWS) 
Rastatt, Germany and Prof O. Ohnishi, Kyoto University, Japan, respectively. Seeds were planted in pots. At the beginning of the flowering stage, Sobano plants with long styles and short stamens (pin) were crossed as female parents with $\mathrm{HOMO}$ as male parent. HOMO is homostyle and self-fertile and their hybrids are all self-fertile. They produced an $F_{2}$ generation that gave raise to $F_{3}$ seeds after selfing. The parents, $F_{1}$ and $F_{2}$ progenies were grown in pots in a growth chamber and were analyzed for inheritance of the seed protein subunits by means of SDS-PAGE.

\subsection{Preparation of Seed Protein Samples}

The preparation of the protein sample of each seed for SDS-PAGE electrophoresis followed Li et al. (2008).

In order to compare the differences of seed protein subunits in the seeds, cotyledons, and endosperm they were sampled separately. The procedures were as follows: The seeds were immerged in $30 \mathrm{ml}$ didistilled water $\left(\mathrm{ddH}_{2} \mathrm{O}\right)$ at $4{ }^{\circ} \mathrm{C}$ for 24 hours. These parental seeds were removed from its seed coat and dissected into cotyledon and endosperm. The separated cotyledon and endosperm of Sobano and HOMO were sampled separately according to the above procedure.

\subsection{SDS-PAGE Electrophoresis and Analysis of Data}

SDS-PAGE electrophoresis and Analysis of data all followed Li et al. (2008). Besides, Chi square test was used for significance analysis of the genetic model (allelic analysis, single factor analysis, independent and linkage analysis) on the morphological characters and seed protein subunits at 0.01 level.

When a seed protein subunit band of HOMO can be regarded as a recessive gene in a co-dominant model, the crossover value between relative characters was calculated according to the formula: for coupling phase, crossover value $(\%)=1-2 \sqrt{\text { completepure recessivegenotyperate }}$; for repulsion phase, crossover value $(\%)=2$ $\sqrt{\text { complete pure recessive genotype rate }}$.

\subsection{Inheritance of Morphological Characters}

Cultivated $F$. esculentum is a self-incompatible species with heterostylic pin and thrum flowers. The wild type HOMO is self-compatible, expressing homostylic flowers. Due to this trait the latter is being used for improving cultivated buckwheat. HOMO possesses seed shattering which is associated with the presence of an abscission layer across the pedicel (Oba et al., 1998). Common buckwheat is resistant to shattering. Acute achenes possess three thorny edges as in HOMO, the edges of blunt archenes are like an arch (Figure 1) as in the cultivar Sobano. The characters of the parents, $F_{1}$, and $F_{2}$ plants, including homostyly/heterostyly, shattering/non-shattering and blunt/acute achene were scored for inheritance.
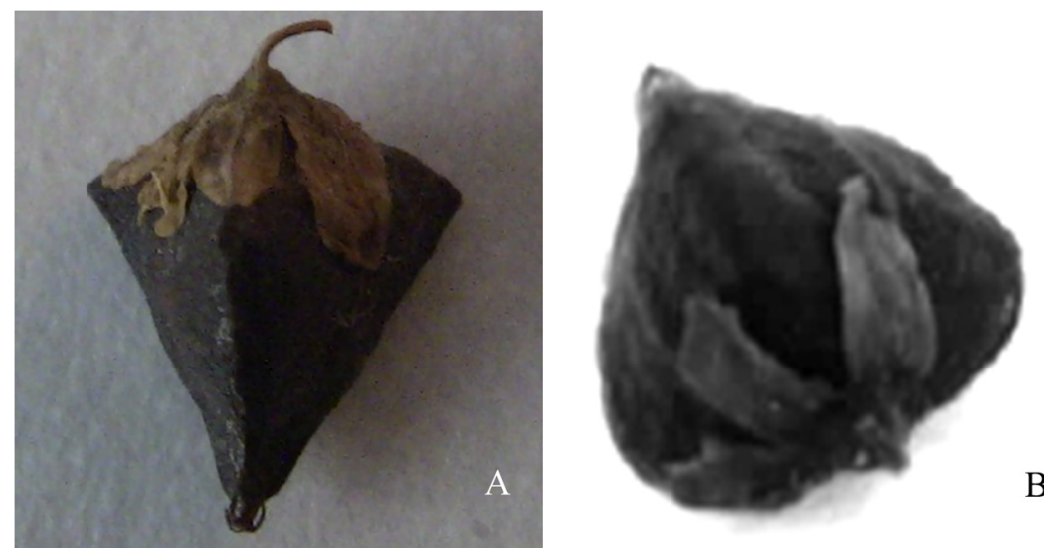

Figure 1. The morphological comparison between acute (A, from HOMO) and blunt (B, from Sobano) achenes

\section{Results}

\subsection{Protein Subunits in Cotyledon and Endosperm Tissue of Parental Seeds}

The spectra and ideograms of protein subunits in the cotyledon (C) and endosperm (E) of the parental seeds (S) are illustrated in Figures 2 and 3. The molecular weights of the protein subunits of the seeds, cotyledon and endosperm of the common buckwheat cultivar Sobano are in the range of 11.4-86.6 kDa, 11.4-86.6 kDa, and 17-60 kDa, respectively. There are 33 bands in the seeds, 33 in the cotyledon, and nine in the endosperm. The number of protein subunits in the endosperm is much less than those in seeds and cotyledons and the bands $\mathrm{PS}_{17.0}, \mathrm{PS}_{22.5}$, 
$\mathrm{PS}_{23.2}, \mathrm{PS}_{33.3}, \mathrm{PS}_{35.0}, \mathrm{PS}_{37.4}, \mathrm{PS}_{41.8}, \mathrm{PS}_{50}, \mathrm{PS}_{60}$ are shared in seeds and cotyledons, indicating few protein subunits in the endosperm.

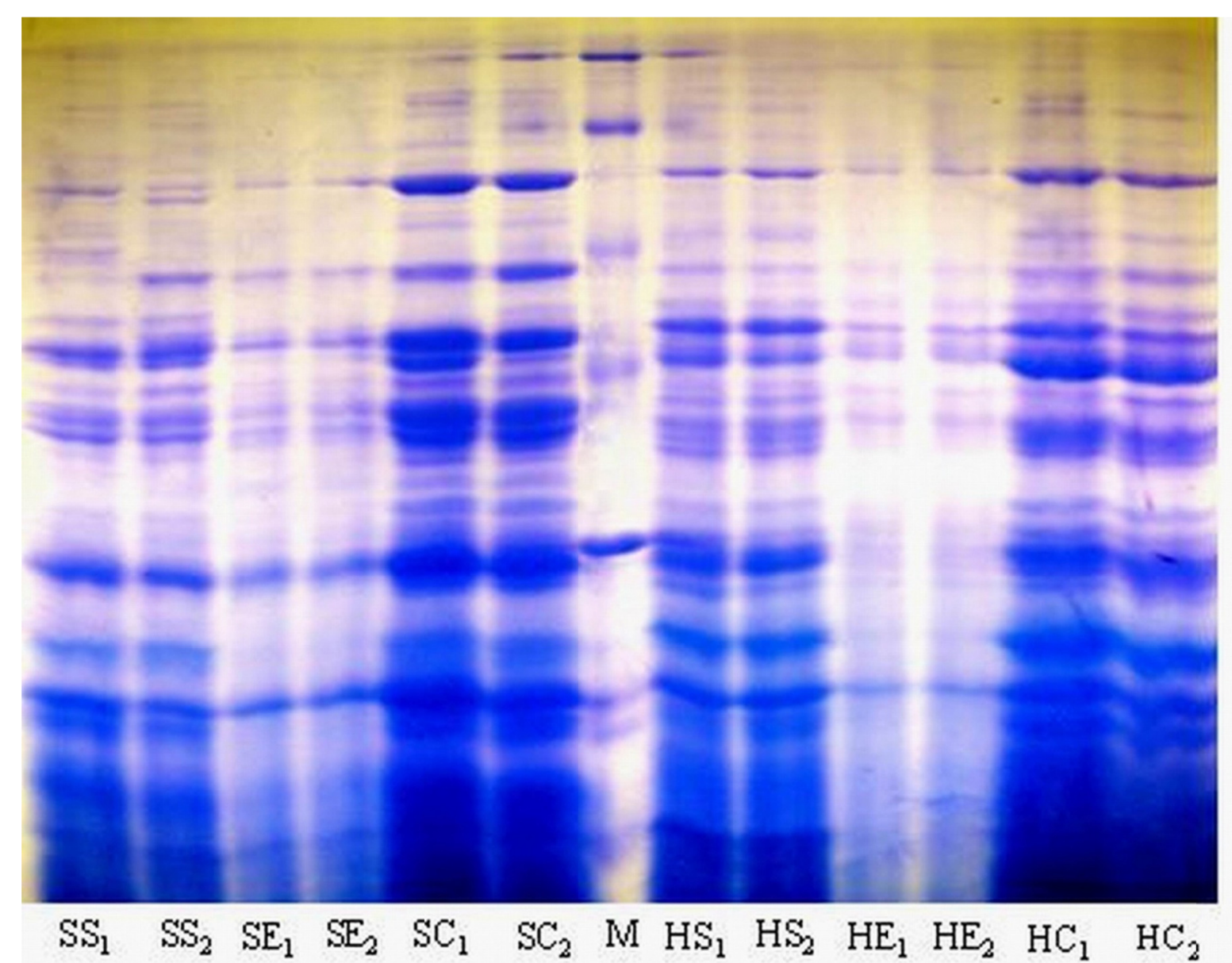

Figure 2. The SDS-PAGE spectrum of seeds, cotyledons and endosperms of Sobano and HOMO

Note: $\mathrm{SS}_{1}, \mathrm{SS}_{2}=$ Sobano seed protein subunits. $\mathrm{SC}_{1}, \mathrm{SC}_{2}=$ Sobano cotyledon protein subunits. $\mathrm{SE}_{1}, \mathrm{SE}_{2}=$ Sobano endosperm protein subunits $\mathrm{HS}_{1}, \mathrm{HS}_{2}=\mathrm{HOMO}$ seed protein subunits. $\mathrm{HC}_{1}, \mathrm{HC}_{2}=\mathrm{HOMO}$ cotyledon protein subunits. $\mathrm{HE}_{1}, \mathrm{HE}_{2}=\mathrm{HOMO}$ endosperm protein subunits $\mathrm{M}=$ molecular weight markers. 


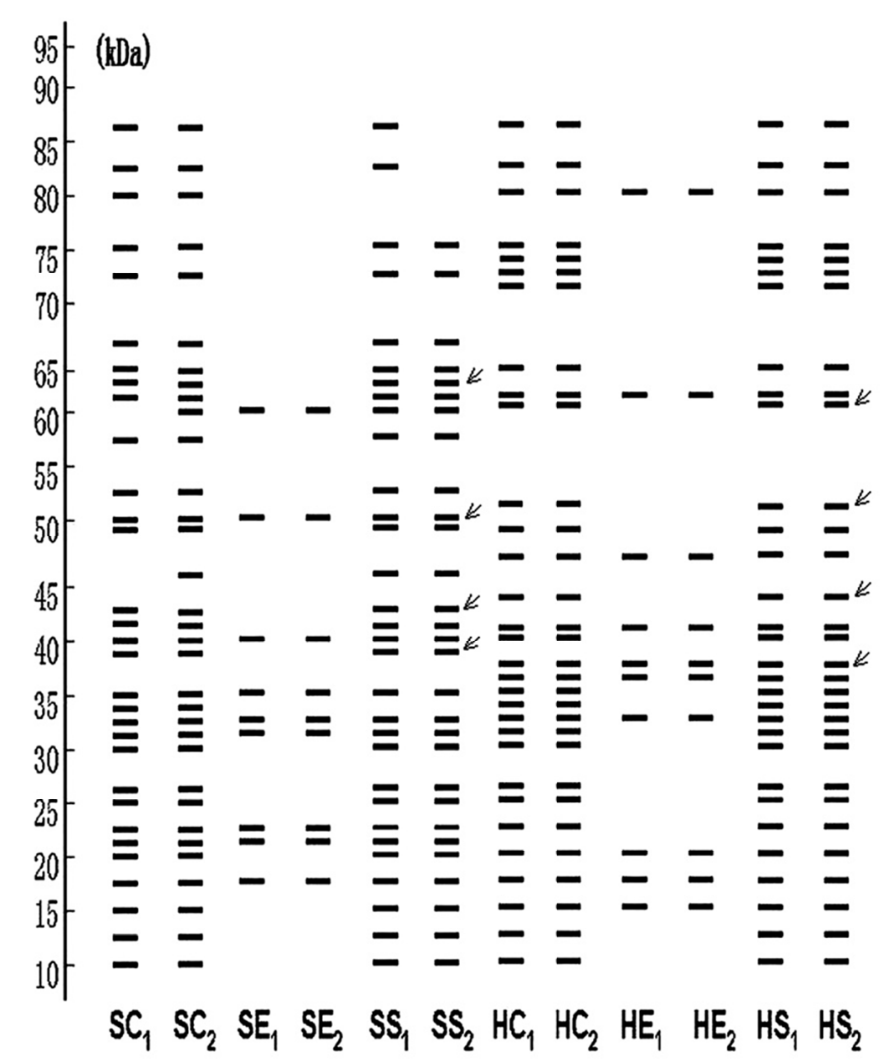

Figure 3. The idiogram of protein subunits of Sobano, HOMO seeds, cotyledons and endosperms

Note: $\mathrm{SS}_{1}, \mathrm{SS}_{2}=$ Sobano seed protein subunits. $\mathrm{SC}_{1}, \mathrm{SC}_{2}=$ Sobano cotyledon protein subunits. $\mathrm{SE}_{1}, \mathrm{SE}_{2}=\mathrm{Sobano}$ endosperm protein subunits $\mathrm{HS}_{1}, \mathrm{HS}_{2}=\mathrm{HOMO}$ seed protein subunits. $\mathrm{HC}_{1}, \mathrm{HC}_{2}=\mathrm{HOMO}$ cotyledon protein subunits. $\mathrm{HE}_{1}, \mathrm{HE}_{2}=\mathrm{HOMO}$ endosperm protein subunits. The four pairs of seed protein subunits (PS62/PS59, PS44/PS42.9, PS49.8/PS51.4, and PS39.9/PS37.8) are marked with arrows.

The molecular weights of the protein subunits of the seeds and cotyledons in HOMO shared the same range as those in Sobano. However, the subunits of the HOMO endosperm have a larger range (15.0-80.8 $\mathrm{kDa})$ than those in Sobano. HOMO has 31 bands in the seeds, 31 in the cotyledon, and ten in the endosperm. There are few variations among different seeds of $\mathrm{HOMO}$, and most of its protein subunits in the cotyledon are the same as in Sobano. The cotyledons and seeds in HOMO share 26 bands and the endosperm they shares only nine bands ( $\mathrm{PS}_{15}$, $\mathrm{PS}_{17.0}, \mathrm{PS}_{20.8}, \mathrm{PS}_{33.3}, \mathrm{PS}_{35.0}, \mathrm{PS}_{37.4}, \mathrm{PS}_{41.8}, \mathrm{PS}_{47}, \mathrm{PS}_{62.5}$, and $\mathrm{PS}_{80.8}$ ). It is evident that the seed protein subunits in Sobano and HOMO are all mainly distributed in the cotyledon and few in the endosperm.

Sobano and HOMO have nine $\left(\mathrm{PS}_{37}, \mathrm{PS}_{39.9}, \mathrm{PS}_{42.9}, \mathrm{PS}_{46}, \mathrm{PS}_{49.8}, \mathrm{PS}_{50}, \mathrm{PS}_{57.4}, \mathrm{PS}_{60}, \mathrm{PS}_{62}\right)$ and ten $\left(\mathrm{PS}_{36.5}, \mathrm{PS}_{37.8}\right.$, $\mathrm{PS}_{40.6}, \mathrm{PS}_{44.0}, \mathrm{PS}_{47.0}, \mathrm{PS}_{48.4}, \mathrm{PS}_{51.4}, \mathrm{PS}_{59}, \mathrm{PS}_{72.7}, \mathrm{PS}_{74.6}$ ) protein subunits in the seeds and cotyledons, respectively. These special bands in the seeds of Sobano and HOMO are considered as genetic markers in genetic analysis of seed protein subunits. The number of protein subunits in the endosperm of Sobano and HOMO are much less than in the seeds and cotyledons, but most of them are different from each other, that is, the special bands of endosperm in Sobano are $\mathrm{PS}_{22.5}, \mathrm{PS}_{23.2}, \mathrm{PS}_{40}, \mathrm{PS}_{50}, \mathrm{PS}_{60}$, different from those $\left(\mathrm{PS}_{15}, \mathrm{PS}_{20.8}, \mathrm{PS}_{42.5}, \mathrm{PS}_{47}, \mathrm{PS}_{62.5}, \mathrm{PS}_{80.8}\right)$ in HOMO.

\subsection{The Inheritance of Seed Protein Subunits}

\subsubsection{Allelism Analysis}

The segregation of protein subunits in $63 \mathrm{~F}_{2}$ progenies and $80 \mathrm{~F}_{2}$ progenies inferred from $\mathrm{F}_{3}$ lines are listed in Table 1. The two types of $\mathrm{F}_{2}$ progenies show eight bands $\left(\mathrm{PS}_{62}, \mathrm{PS}_{59}, \mathrm{PS}_{49.8}, \mathrm{PS}_{51.4}, \mathrm{PS}_{44}, \mathrm{PS}_{42.9}, \mathrm{PS}_{39.9}, \mathrm{PS}_{37.8}\right)$ having a clear genetic segregation and fitting a rate of 3 (having the band) : 1 (lacking the band). After combination of any two bands randomly and testing the two bands as a pair of alleles they fit a rate of 1(having a band) : 2 (having both of the two bands) : 1 (having another band), it is evident that there are four pairs of alleles $\left(\mathrm{PS}_{62} / \mathrm{PS}_{59}, \mathrm{PS}_{49.8} / \mathrm{PS}_{51.4}\right.$, $\mathrm{PS}_{44} / \mathrm{PS}_{42.9}$, and $\mathrm{PS}_{39.9} / \mathrm{PS}_{37.8}$ ) fitting the co-dominant model of four alleles (Table 1). 
Table 1. Segregation of four pairs of protein subunits in $63 \mathrm{~F}_{2}$ progenies $\left(\mathrm{F}_{2}\right)$ and $80 \mathrm{~F}_{2}$ progenies inferred from $\mathrm{F}_{3}$ lines $\left(\mathrm{F}_{2}{ }^{*}\right)$

\begin{tabular}{cccccc}
\hline Progenies & Subunits & Segregation & Ratio & $\chi^{2}$ & Probability \\
\hline $\mathrm{F}_{2}$ & PS62 / PS59 & $14: 33: 16$ & $1: 2: 1$ & 0.269 & $>0.05$ \\
& PS49.8 / PS51.4 & $15: 32: 16$ & $1: 2: 1$ & 0.016 & $>0.05$ \\
& PS44 / PS42.9 & $16: 30: 17$ & $1: 2: 1$ & 0.110 & $>0.05$ \\
& PS39.9 / PS37.8 & $15: 31: 17$ & $1: 2: 1$ & 0.143 & $>0.05$ \\
$\mathrm{~F}_{2}{ }^{*}$ & PS62 / PS59 & $25: 36: 19$ & $1: 2: 1$ & 2.900 & $>0.05$ \\
& PS49.8 / PS51.4 & $27: 37: 17$ & $1: 2: 1$ & 3.675 & $>0.05$ \\
& PS44 / PS42.9 & $15: 42: 23$ & $1: 2: 1$ & 2.600 & $>0.05$ \\
& PS39.9 / PS37.8 & $19: 45: 16$ & $1: 2: 1$ & 1.475 & $>0.05$ \\
\hline
\end{tabular}

\subsubsection{Linkage Analysis}

The segregation of the alleles of four pairs of protein subunit in $63 \mathrm{~F}_{2}$ progenies and $80 \mathrm{~F}_{2}$ progenies inferred from $\mathrm{F}_{3}$ lines are listed in Table 2 . The combinations of any two pairs of alleles fit a ratio of 4:2:2:2:2:1:1:1:1, indicating an independent inheritance and the locations in different linkage groups.

Table 2. The segregation of two protein subunit alleles in $63 \mathrm{~F}_{2}$ progenies $\left(\mathrm{F}_{2}\right)$ and $80 \mathrm{~F}_{2}$ progenies inferred from $\mathrm{F}_{3}$ lines $\left(\mathrm{F}_{2}{ }^{*}\right)$

\begin{tabular}{llllll}
\hline Progenies & Subunits & Segregation & Ratio & $\chi^{2}$ & Probability \\
\hline $\mathrm{F}_{2}$ & PS62 / PS59 & $18: 10: 7: 11: 8: 7: 5: 5: 7$ & $(1: 2: 1)^{2}=4: 2: 2: 2: 2: 1: 1: 1: 1$ & 7.201 & $>0.05$ \\
& - PS49.6 / PS51.4 & & & & \\
& PS62 / PS59 & $17: 9: 9: 11: 12: 6: 4: 4: 5$ & $(1: 2: 1)^{2}=4: 2: 2: 2: 2: 1: 1: 1: 1$ & 1.539 & $>0.05$ \\
& - PS44 / PS42.9 & & & & \\
& PS62 / PS59 & $16: 10: 9: 16: 13: 4: 3: 5: 3$ & $(1: 2: 1)^{2}=4: 2: 2: 2: 2: 1: 1: 1: 1$ & 5.063 & $>0.05$ \\
& - PS39.9/ PS37.8 & & & & \\
& PS49.8 / PS51.4 & $20: 11: 5: 15: 4: 4: 3: 5: 8$ & $(1: 2: 1)^{2}=4: 2: 2: 2: 2: 1: 1: 1: 1$ & 2.004 & $>0.05$ \\
& - PS44 / PS42.9 & & & & \\
& PS49.8/ PS51.4 & $25: 6: 6: 8: 10: 9: 5: 4: 3$ & $(1: 2: 1)^{2}=4: 2: 2: 2: 2: 1: 1: 1: 1$ & 2.205 & $>0.05$ \\
& - PS39.9/PS37.8 & & & & \\
& PS44 / PS42.9 & $24: 12: 5: 11: 11: 5: 2: 1: 5$ & $(1: 2: 1)^{2}=4: 2: 2: 2: 2: 1: 1: 1: 1$ & 9.176 & $>0.05$ \\
& - PS39.9/PS37.8 & & & & \\
& PS62/PS59 & $19: 7: 4: 5: 8: 3: 7: 6: 4$ & $(1: 2: 1)^{2}=4: 2: 2: 2: 2: 1: 1: 1: 1$ & 3.200 & $>0.05$ \\
& - PS49.6/PS51.4 & & & & \\
& PS62/PS59 & $13: 9: 7: 8: 10: 3: 4: 4: 4$ & $(1: 2: 1)^{2}=4: 2: 2: 2: 2: 1: 1: 1: 1$ & 2.350 & $>0.05$ \\
& - PS44/PS42.9 & & & & \\
& PS62/PS59 & $13: 8: 8: 7: 8: 3: 3: 4: 2$ & $(1: 2: 1)^{2}=4: 2: 2: 2: 2: 1: 1: 1: 1$ & 6.900 & $>0.05$ \\
& - PS39.9/PS37.8 & & & & \\
& PS49.8/PS51.4 & $14: 5: 10: 5: 11: 6: 4: 5: 3$ & $(1: 2: 1)^{2}=4: 2: 2: 2: 2: 1: 1: 1: 1$ & 10.300 & $>0.05$ \\
& - PS44/PS42.9 & & & & \\
& PS49.8/PS51.4 & $17: 9: 7: 8: 7: 3: 3: 3: 6$ & $(1: 2: 1)^{2}=4: 2: 2: 2: 2: 1: 1: 1: 1$ & 10.300 & $>0.05$ \\
& $-P S 39.9 / P S 37.8$ & & $(1: 2: 1)^{2}=4: 2: 2: 2: 2: 1: 1: 1: 1$ & 8.900 & $>0.05$ \\
& PS44/PS42.9 & $18: 8: 5: 8: 4: 7: 5: 4: 8$ & & & \\
& - PS39.9/PS37.8 & & & &
\end{tabular}




\subsection{The Inheritance of Morphological Characters}

All five plants of the $\mathrm{F}_{1}$ hybrids between Sobano and HOMO showed homostyly, acute achenes, and the shattering habit, indicating a dominant mode of inheritance. Segregations of the three morphological characters in $F_{2}$ progenies are listed in Table 3. It is clear that all three pairs of alleles (homostyle/heterostyle, shattering /non-shattering and acute/blunt achene fit a ratio of 3:1, indicating the inheritance model of one pair of alleles.

Table 3. Segregation of three morphological characters in $80 \mathrm{~F}_{2}$ progenies inferred from $\mathrm{F}_{3}$ lines $\left(\mathrm{F}_{2}{ }^{*}\right)$

\begin{tabular}{llllllll}
\hline characters & Sobano $(+)$ & $F h\left({ }^{\Uparrow}\right)$ & $\mathrm{F}_{1}$ & $\mathrm{~F}_{2}{ }^{*}$ segregation & Ratio & $\mathrm{x}^{2}$ & Probability \\
\hline style & long style & homostyle & homostyle & $63: 17$ & $3: 1$ & 0.750 & $>0.05$ \\
achene & blunt & acute & acute & $57: 23$ & $3: 1$ & 0.600 & $>0.05$ \\
shattering & Non & yes & yes & $59: 21$ & $3: 1$ & 0.022 & $>0.05$ \\
\hline
\end{tabular}

The linkage analyses of the morphological characters are listed in Table 4. The segregation of homostyly and shattering habit do not fit the ratio of 9:3:3:1, indicating a linkage relationship of 7.81\% $(=1-2 \times \sqrt{17 / 80})$. Since the segregation of the two pairs of relative characters and the achene (acute / blunt) fit the ratio of 9:3:3:1, they are all independent of the achene character (acute / blunt).

Table 4. Segregation of three pairs of relative characters in $F_{2}$ progenies

\begin{tabular}{ccccc}
\hline Characters & Segregation & Ratio & $\chi^{2}$ & Probability \\
\hline $\begin{array}{c}\text { homostyle/ heterostyle } \\
\text { - shattering /non-shattering } \\
\text { homostyle/ heterostyle }\end{array}$ & $60: 1: 2: 17$ & $(3: 1)(3: 1)=9: 3: 3: 1$ & $58.134^{* *}$ & $<0.01$ \\
$\begin{array}{c}\text { - acute achene/blunt achene } \\
\text { Acute achene/blunt achene }\end{array}$ & $45: 11: 18: 6$ & $(3: 1)(3: 1)=9: 3: 3: 1$ & 1.867 & $>0.05$ \\
\begin{tabular}{c} 
- shattering /non-shattering \\
\hline
\end{tabular} & $39: 17: 17: 7$ & $(3: 1)(3: 1)=9: 3: 3: 1$ & 2.134 & $>0.05$ \\
\hline
\end{tabular}

\subsection{The Linkage Analysis of Morphological Characters and Seed Protein Subunits}

The segregation of morphological characters and seed protein subunits in $80 \mathrm{~F}_{2}$ progenies inferred from $\mathrm{F}_{3}$ lines are listed in Table 5. Only the segregation of $\mathrm{PS}_{44} / \mathrm{PS}_{42.9}$ and shattering habit does not fit the ratio of 3:6:3:1:2:1, indicating a linkage relationship of $22.54 \%(=1-2 \sqrt{12 / 80})$.

Table 5. The segregation of morphological characters and seed protein subunits in $80 \mathrm{~F}_{2}$ progenies inferred from $\mathrm{F}_{3}$ lines $\left(\mathrm{F}_{2}{ }^{*}\right)$

\begin{tabular}{ccccc}
\hline Characters / subunits & Segregation & Ratio & $\chi^{2}$ & Probability \\
\hline $\begin{array}{c}\text { homostyle / heterostyle } \\
\quad \text { - PS62 / PS59 }\end{array}$ & $25: 36: 19$ & $(3: 0)(1: 2: 1)=3: 6: 3$ & 2.900 & $>0.05$ \\
$\begin{array}{c}\text { homostyle / heterostyle } \\
\text { - PS49.8 / PS51.4 } \\
\text { homostyle / heterostyle } \\
\quad \text { - PS44 / PS42.9 }\end{array}$ & $27: 37: 17$ & $(3: 0)(1: 2: 1)=3: 6: 3$ & 3.675 & $>0.05$ \\
$\begin{array}{c}\text { homostyle / heterostyle } \\
\text { - PS39.9 / PS37.8 }\end{array}$ & $15: 42: 23$ & $(3: 0)(1: 2: 1)=3: 6: 3$ & 2.600 & $>0.05$ \\
$\begin{array}{c}\text { Acute / blunt achene } \\
\text { - PS62 / PS59 }\end{array}$ & $17: 24: 12: 6: 16: 5$ & $(3: 1)(1: 2: 1)=3: 6: 3: 1: 2: 1$ & 5.867 & $>0.05$ \\
Acute / blunt achene & $17: 25: 12: 6: 13: 7$ & $(3: 1)(1: 2: 1)=3: 6: 3: 1: 2: 1$ & 3.600 & $>0.05$
\end{tabular}


- PS49.8/ PS51.4

\begin{tabular}{lllll}
$\begin{array}{c}\text { Acute / blunt achene } \\
\text { - PS44 / PS 42.9 }\end{array}$ & $16: 24: 13: 6: 12: 5$ & $(3: 1)(1: 2: 1)=3: 6: 3: 1: 2: 1$ & 2.133 & $>0.05$ \\
$\begin{array}{c}\text { Acute / blunt achene } \\
\text { - PS39.9 / PS37.8 }\end{array}$ & $15: 26: 10: 8: 15: 6$ & $(3: 1)(1: 2: 1)=3: 6: 3: 1: 2: 1$ & 5.700 & $>0.05$ \\
$\quad \begin{array}{l}\text { Shattering habit } \\
\text { - PS62 / PS59 }\end{array}$ & $14: 29: 9: 7: 15: 6$ & $(3: 1)(1: 2: 1)=3: 6: 3: 1: 2: 1$ & 6.000 & $>0.05$ \\
Shattering habit & $15: 25: 12: 8: 18: 2$ & $(3: 1)(1: 2: 1)=3: 6: 3: 1: 2: 1$ & 11.133 & $>0.05$ \\
- PS49.8 / PS51.4 & & & & \\
Shattering habit & $24: 38: 1: 0: 0: 12$ & $(3: 1)(1: 2: 1)=3: 6: 3: 1: 2: 1$ & $47.467^{* * *}$ & $<0.01$ \\
- PS44 / PS 42.9 & & & & \\
Shattering habit & $17: 28: 8: 8: 16: 5$ & $(3: 1)(1: 2: 1)=3: 6: 3: 1: 2: 1$ & 6.018 & $>0.05$ \\
- PS39.9 / PS37.8 & & & & \\
\hline
\end{tabular}

\section{Discussion}

Krkoskova and Mrazova (2005) reported that the protein content in buckwheat seeds ranges from 8 to $19 \%$, mainly distributed in the aleurone layer and the cotyledon. This study showed that most of seed protein subunits in Sobano and HOMO are distributed in the cotyledon and in endosperm, which is consistent with Maksimovic et al. (1996). Zeller et al. (2004) revealed that two pairs of seed protein subunits (20-25 kD) in the globulin fraction of the seeds fit a co-dominant monogenic mode of inheritance. The present study showed the inheritance of the protein subunits $37-62 \mathrm{kD}$ in the cotyledon of the seeds and found four alleles controlling four pairs of protein subunits controlled by a single co-dominant allele. It further found the inheritance of the protein subunits (37-62 $\mathrm{kD}$ ) in the cotyledons of the seeds and detected four alleles controlling four pairs of seed protein subunits fitting a co-dominant and single gene pattern in different linkage groups.

In the present study, a one-gene model is postulated for the inheritance of self-compatibility and flower morphology when common buckwheat is crossed with the wild HOMO. Woo et al. (1997), Campbell (1998), Wang and Campbell (1998) and Zeller and Hsam (2001) also proposed the same model for the inheritance of flower morphology. The homomorphic flower type of HOMO is expressed by the allele $S^{h}$. The complex in cultivated $F$. esculentum is governed by a single locus $S$ with two alleles $S$ and $s$ that control the reaction in the two types of heteromorphic plants. The relationships between the alleles which produce the three types of flours were described as $S>S^{h}>s$. Aii et al. (1998) have identified a RAPD marker tightly linked to the $S$ allele at a distance of $0.6 \mathrm{cM}$. Wang et al. (2005b), however, suggest a two complementary dominant gene loci model in which the loci $S^{h}$ and $S_{c}$ control self-compatibility in HOMO with three alleles at the first locus $S^{h}$ and two alleles at the second locus $S_{c}$.

In the present study a single dominant gene was found being responsible for seed shattering confirming Ohnishi (1999) who detected in F.esculentum ssp. ancestrale, the ancestor of common buckwheat, also governing by single locus . Matsui et al. (2003), however, using self-compatible lines derived from an interspecific cross between cultivated $F$. esculentum and the wild type HOMO found that the shattering habit is controlled by two complementary dominant genes. Five AFLP markers were linked to one locus (sht1) and two of these markers co-segregated with the shattering locus without recombination (Matsui et al., 2004). Wang et al. (2005a) postulated for the inheritance of the shattering character the presence of three complementary dominant genes. In the present study a linkage of $7.81 \%$ between the genes for shattering and homostyly was observed confirming a previous report by Fesenko et al. (1998). Furthermore this study showed a linkage between the allele pair of shattering and the locus for the seed protein subunits $\mathrm{PS}_{44} / \mathrm{PS}_{42.9}$ of $22.54 \%$.

The trait acute/blunt achenes, to our knowledge for the first time described, follows a dominant mode of inheritance being controlled by a dominant gene.

Since all of $\mathrm{F}_{2}$ progenies inferred from $\mathrm{F}_{3}$ lines produced by selfing of $\mathrm{F}_{2}$ plants being homostyly were homostyly, we could not obtain the exchange value of homostyly with PS39.9/ PS37.8. It is clear, however, that there is a linkage group of the three loci for shattering habit, homostyly and the protein subunits PS44/ PS 42.9 and the 
exchange rate of $\mathrm{PS}_{42} / \mathrm{PS}_{42.9}$ and homostyly $(H / s)(\%)$ is $22.54 \%+/-7.81 \%=30.35 \% / 14.73 \%$. Chen et al. (2007) reported that the $\mathrm{s}$ gene for long style is located on buckwheat chromosome $4 \mathrm{E}$ by means of trisomic lines.

According to the above analysis, there may be six linkage groups discovered in this study, that is, a linkage group of three alleles: shattering, homostyly, and protein subunits PS44 / PS 42.9 and four linkage groups covering three alleles of seed protein subunits and one locus for the acute achene character, respectively.

\section{Acknowledgment}

The authors thank the Natural Science Foundation of China (31060207, 31171609), the Earmarked Fund for China Agriculture Research System (CARS-08-A4), Guizhou Key Agricultural Project (QianKeHe NY Zi [2010]3094), and the Project of the Scientific and Technological Innovation Teams in Guizhou (QianKeHe RenCai TuanDui [2011]4007) for providing funds, and to the International Science Editing ( www.internationalscienceediting.cn) for proofing the English.

\section{References}

Aii, I., Penner, G. A., Clayton, C. G., \& Adachi, T. (1998). Identification of RAPD markers to the homostylar Ho gene in buckwheat. Breeding Sci., 48, 59-62.

Bonafaccia, G., Marocchini, M., \& Kreft, I. (2003). Composition and technological properties of the flour and bran from common and tartary buckwheat. Food Chem., 80, 9-15. http://dx.doi.org/10.1016/S0308-8146(02)00228-5

Campbell, C. G. (1995). Inter-specific hybridization in genus Fagopyrum. Proceedings of the $6^{\text {th }}$ International Buckwheat Symposium (pp. 255-263). Ina, Japan.

Campbell, C. G. (1997). Buckwheat, Fagopyrum esculentum Moench. Promoting the conservation and use of underutilized and neglected crops. 19. Institut fuer Pflanzengenetik und Kulturpflanzenforschung, Gatersleben/International Plant Genetic Resources Institute, Rome, Italy.

Chen, Q. F. (Ed.) (2012). Plant Sciences on genus Fagopyrum. Beijing, China: Science Press.

Chen, Q. F., Hsam, S. L. K., \& Zeller, F. J. (2007). Cytogenetic studies on diploid and autotetraploid common buckwheat and their autotriploid and trisomics. Crop Sci, 47, 2340-2345. http://dx.doi.org/10.2135/cropsci2007.03.0130

Dvoracek, V., Cepkova, P., Michalova, A., \& Kreft, I. (2004). Seed storage protein polymorphism of buckwheat varieties (Fagopyrum esculentum Moench; Fagopyrum tataricum L.). Proceedings of the $9^{\text {th }}$ International Buckwheat Symposium (pp. 412-418). Prague, Czech Republic.

Fesenko, N. N., Fesenko, A. N., \& Ohnishi, O. (1998). Some genetic pecularities of reproductive systems of wild relatives of common buckwheat Fagopyrum esculentum Moench. Proceedings of the $7^{\text {th }}$ International Buckwheat Symposium, Winnipeg, Canada (pp. 32-35).

Guo, X., \& Yao, H. (2006). Fractionation and characterization of tartary buckwheat flour proteins. Food Chem, 98, 90-94. http://dx.doi.org/10.1016/j.foodchem.2005.05.055

Khan, N., Takahashi, Y., \& Katsube T. (2012). Tandem repeat inserts of 13S globulin subunits, the major allergenic storage protein of common buckwheat (Fagopyrum esculentum Moench) seeds. Food Chem, 133, 29-37. http://dx.doi.org/10.1016/j.foodchem.2011.12.056

Krkoskova, B., \& Mrazova, Z. (2005). Prophyactic components of buckwheat. Food Res Intern, 38, $561-568$. http://dx.doi.org/10.1016/j.foodres.2004.11.009

Lazareva, T. N., \& Fesenko, I. N. (2004). Electrophoresis spectra of total seed proteins of artificial amphidiploid Fagopyrum giganteum Krotov and its parental species F. tartaricum Gaertn and F. cymosum Meisn. Proceedings of the $9^{\text {th }}$ International Buckwheat Symposium (pp. 299-301). Prague, Czech Republic.

Li, J. H., Chen, Q. F., \& Zeller, F. J. (2008). Variation in seed protein subunits among species of the genus Fagopyrum Mill. Plant Syst Evol, 274, 193-202. http://dx.doi.org/10.1007/s00606-008-0048-5

Maksimovic, V. R., Varkonji-Gasic, E. I., Radovic, S. R., \& Savic, A. P. (1996). The biosynthesis of 13S buckwheat seed storage protein. J Plant Physiol, 147, $759-761$. http://dx.doi.org/10.1016/S0176-1617(11)81490-2

Matsui, K., Kiryu, Y., Komatsuda, N., Ohtani, T., \& Tetsuka. (2004). Identification of AFLP markers linked to non-seed shattering locus (sht1) in buckwheat and conversion to STS markers for marker-assisted selection. Genome, 47, 469-474. http://dx.doi.org/10.1139/g04-007 
Matsui, K., Tetsuka, T., \& Hara, T. (2003). Two independent gene locicontrolling non-brittle pedicel in buckwheat. Euphytica, 134, 203-208. http://dx.doi.org/10.1023/B:EUPH.0000003911.70493.cd

Nalecz, D., Dziuba, J., Minkiewicz, Dziuba, M., \& Szerscunowicz, I. (2009). Identification of oat (Avena sativa) and buckwheat (Fagopyrum esculentum) proteins and their prolamin fractions using two-dimensional polyacridamide gel electrophoresis. Eur Food Res Technol, 230, 71-78. http://dx.doi.org/10.1007/s00217-009-1143-8

Oba, S., Ohta, A., \& Fujimoto. (1998). Grain shattering habit of buckwheat. Proceedings of the $7^{\text {th }}$ International Buckwheat Symposium (pp. 12-14). Winnipeg, Canada.

Ohnishi, O. (1995). Discovery of new Fagopyrum species and its implication for the studies of evolution of Fagopyrum and of the origin of cultivated buckwheat. Proceedings of the $6^{\text {th }}$ International Buckwheat Symposium (pp. 175-190). Ina, Japan. http://dx.doi.org/10.1023/A:1008640522979

Ohnishi, O., \& Asano, N. (1999). Genetic diversity of Fagopyrum homotropicum, a wild species related to common buckwheat. Genet Resour Crop Evol, 46, 389-3981.

Radovic, S. R., Maksimovic, V. R., \& Varconji-Gasic, E. I. (1996). Characterization of buckwheat seed storage proteins. $J$ Agric Food Chem, 44, 972-974. http://dx.doi.org/10.1021/jf950655x

Rogl, S., \& Javornik, B. (1996). Seed protein variation for identification of common buckwheat (Fagopyrum esculentum Moench) cultivars. Euphytica, 87, 111-117. http://dx.doi.org/10.1007/BF00021883

Rout, A., \& Chrungoo, N. K. (2007). Genetic variation and species relationships in Himalayan buckwheats as revealed by SDS PAGE by endosperm proteins extracted from single seeds and RAPD based DNA fingerprints. Genet Resour Crop Evol, 54, 767-777. http://dx.doi.org/10.1007/s10722-006-9166-5

Wang, Y., \& Campbell, G. C. (1998). Interspecific hybridization in buckwheat among Fagopyrum esculentum, F. homotropicum and F. tataricum. Proceedings of the $7^{\text {th }}$ International buckwheat Symposium (pp. 1-11), Manitoba, Canada.

Wang, Y., Scarth, R., \& Campbell, G. C. (2005a). Inheritance of seed shattering in interspecific hybrids between Fagopyrum esculentum and F. homotropicum. Crop Sci, 45, 693-697.

Wang, Y., Scarth, R., \& Campbell, G. C. (2005b). $S^{h}$ and $S_{c}$ - two complementary dominant genes that control self-compatibility in buckwheat. Crop Sci, 45, 1229-1234.

Zeller, F. J., \& Hsam, S. L. K. (2001). Genetic analysis and morphological characteristics in common buckwheat (Fagopyrum esculentum Moench). Proceedings of the $8^{\text {th }}$ International Buckwheat Symposium (pp. 214-217). Chunchon, Korea.

Zeller, F. J., Weishaeupl, H., \& Hsam, S. L. K. (2004). Identification and genetics of buckwheat (Fagopyrum) seed storage protein. Proceedings of the $9^{\text {th }}$ International Symposium on Buckwheat (pp. 195-201). Prague, Czech Republic.

\section{Copyrights}

Copyright for this article is retained by the author(s), with first publication rights granted to the journal.

This is an open-access article distributed under the terms and conditions of the Creative Commons Attribution license (http://creativecommons.org/licenses/by/3.0/). 